Sādhanâ, Vol. 9, Part 3, November 1986, pp. 177-190. (C) Printed in India.

\title{
Waterlogging in irrigation projects
}

\author{
B BOWONDER, ${ }^{1 *} \mathrm{~K}$ V RAMANA ${ }^{1}$ and R RAJAGOPAL ${ }^{2}$ \\ 'Centre for Energy, Environment and Technology, Administrative Staff \\ College of India, Hyderabad 500049 , India \\ ${ }^{2}$ Department of Geography, University of Iowa, Iowa City, Iowa 52242 , \\ USA \\ Present address: UN ESCAP, APCTT, 49, Palace Road, Bangalore \\ 560052 , India \\ MS received 12 October 1985
}

\begin{abstract}
Waterlogging is a complex environmental management problem in irrigation projects. Using two irrigation projects as examples the factors contributing to waterlogging have been identified. Policy interventions needed for reducing waterlogging in irrigation projects are identified, such as promoting conjunctive use of surface and ground water, and public demonstration programmes.
\end{abstract}

Keywords. Environmental management; waterlogging; irrigation projects; command area; conjunctive use of water; water management.

\section{Introduction}

Waterlogging and salinity are two major environmental problems that can arise in large irrigation projects (Barney 1980; Bowonder \& Ravi 1983; El-Hinnawi \& Hashmi 1982; National Commission on Agriculture 1976; United Nations 1982; Worthington 1977). In India, about 6 to 10 million hectares of irrigated area suffer from waterlogging (Vohra 1980). In.Pakistan 2.2 million hectares (Federal Bureau of Statistics 1984) are waterlogged, and it is increasing at the rate of 40,000 ha per annum (Bokhari 1980; Dettmann 1983). In China, Egypt, Peru, Argentina, Afghanistan, Kampuchea, Vietnam, Syria and Iran the extent of the problem has been increasing (Barney 1980; Eckholm 1976; Elgabaly 1980a, b, pp. 47-66; Holdgate \& White 1977; Polunin 1979; Ruddle \& Manshard 1981; Smil 1982). Inspite of all this, the problem has received little attention since it is an interface problem of land and water use. Irrigation will have to be sustainable and not destructive through waterlogging and salinity if India's population (i.e., 1,036 million by the year 2000. Agarwal 1985) has to be fed in future years. Currently, about 6 to 10 million hectares of fertile land is waterlogged and agricultural productivity has come down to the extent of $30 \%$ in affected areas (Bowonder \& Ravi 1983, 1984). Soil is an irreplaceable asset and its irreversible degradation has to be arrested through a series of technical, economic and administrative measures. 


\section{Waterlogging as a problem}

Waterlogging is the phenomenon of a rising water-table. If the water-table rises close to the root systems, it affects the oxygen absorption of the roots and the crop yield. Waterlogging is an interactive problem caused by the interplay of factors (figure 1) such as (i) poor drainage provision for surface water; (ii) reduction in the

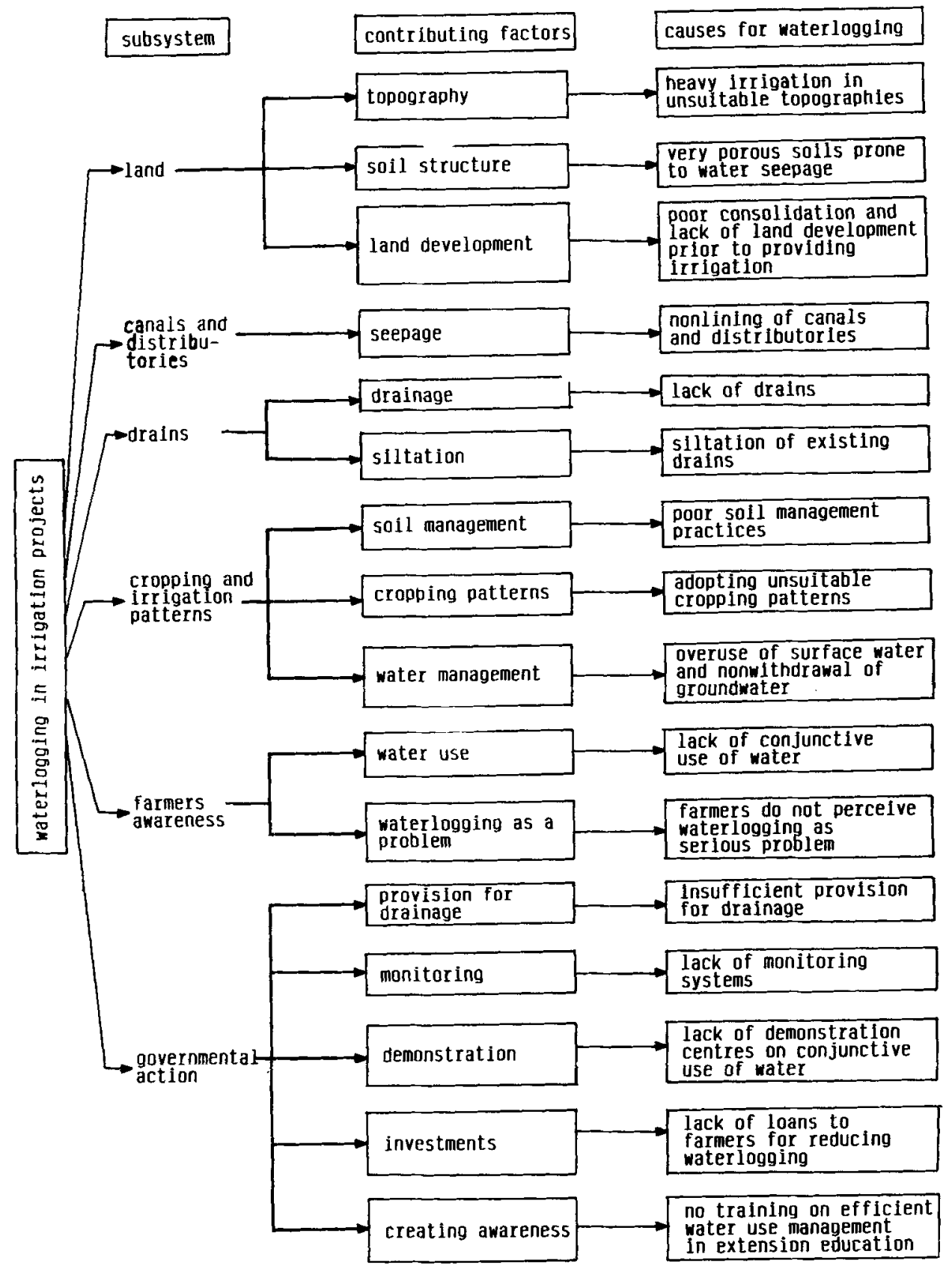

Figure 1. Reasoms for waterlogging in irrigation projects. 
withdrawal of ground water or lack of conjunctive use of ground water; (iii) seepage and percolation from water courses which are not lined; (iv) overuse of water in agriculture caused by poor awareness regarding efficient water use; (v) using crops which are not suitable for the specific soils; (vi) adopting cropping and irrigation patterns not compatible with the area; and (vii) lack of land development prior to the provision of irrigation. The extent of the problem is dependent on topographic factors, soil characteristics, farmers' attitudes and economic factors favouring the use of large quantities of water. Waterlogging disturbs the salt balance and brings up dissolved salts. As moisture in the soil evaporates and transpires salt is left behind if there is no leaching, and this affects the soil quality. When the water-table is within 0 to $3 \mathrm{~m}$ below ground level the soil is said to be waterlogged. Water from this level rises to the root zone through capillary action and reduces the availability of oxygen to the roots.

Waterlogging affects mainly fertile land. Water being a critical component in agriculture in India as well as in other developing countries any loss of irrigated land should be avoided by using proper irrigation practices, provision of drainage, conjunctive use of water etc. The risk of waterlogging arises out of the fact that farmers cannot identify the problem till it starts affecting the yield, and it cannot be arrested unless ground water levels are monitored regularly. Once the levels reach the root zone it is difficult to reverse the problem on an individual basis. Reclamation of affected soils are costly compared to the option of providing drainage (Barney 1980; Brown 1983). In low rainfall areas, in areas with low soil permeability, and in areas with poor natural drainage due to topographic reasons, once the problem of waterlogging becomes severe, reclamation of affected land is difficult since corrective measures yield results slowly.

Waterlogging in irrigation projects.should be viewed with concern because of two reasons. Firstly, waterlogging lowers the yield in fertile soils and wastes water which is a critical input. Secondly, the water which is being wasted has a very high opportunity cost since it could have been used in areas with no irrigation and thus extend the total irrigated area. To sum up, waterlogging thus reduces the potential of producing food in irrigated areas and also prevents extension of irrigation to newer areas, indicating that it has two adverse impacts. This should be viewed in the context that water is going to be a major constraint for increasing agricultural production in India, as can be seen from the situation that in some of the states the demand for water already exceeds the ultimate utilizable potential (Widstrand 1980).

This study analyzes two projects, one (Sriramsagar Project) in which waterlogging has become severe and the other one (Nagarjunasagar Project) in which waterlogging has been reduced.

\section{Sriramsagar Project}

The Sriramsagar (SRS) Project was constructed across the River Godavari to irrigate 0.23 million hectares of land. Of this area, one third was originally planned to be under heavy irrigation (crops requiring large quantities of water) and the rest under light irrigation. The construction of the project started in 1963 and the Kakatiya canal was completed in 1970 . The project was financed by The World 
Bank, and it was stipulated that there should be a continuous monitoring of ground water fluctuations and its quality. As per this stipulation, the Government of Andhra Pradesh has set up a separate cell at Karimnagar to monitor the ground water fluctuations and the changes in the ground water quality in the command area of the Project.

The command area of the SRS project is largely rolling terrain and is sloped towards the Godavari River with slopes ranging from 1 to $3 \%$. There are many low lying areas without systematic drainage facilities.

\subsection{Waterlogging in the SRS command area}

The water-table levels in the command area have been monitored at regular intervals by the Department of Ground Water, Government of Andhra Pradesh. The data were collected from the Department and analyzed to identify the extent of waterlogging in the command area. The monitoring has been done through a series of observation wells (268) distributed in the command area. The water-table levels in the observation wells are monitored in every quarter (April, July, October, January). Firstly, the water-table levels for a number of years are collected from the records of the department. To examine whether waterlogging has been increasing an analysis of water-table levels is carried out, taking premonsoon water-table levels of each year. The data from other seasons will be functions of rainfall since in June rainfall starts. Figure 2 indicates the changes in percentage of wells waterlogged (depth to water-table 0-3 meters from ground level), prone to waterlogging ( 3 to 6 meters from ground level) and free from waterlogging. The number of observation wells in waterlogged condition has increased from 9 to $45 \%$ of the total wells during 1972 to 1984 , whereas observation wells free from

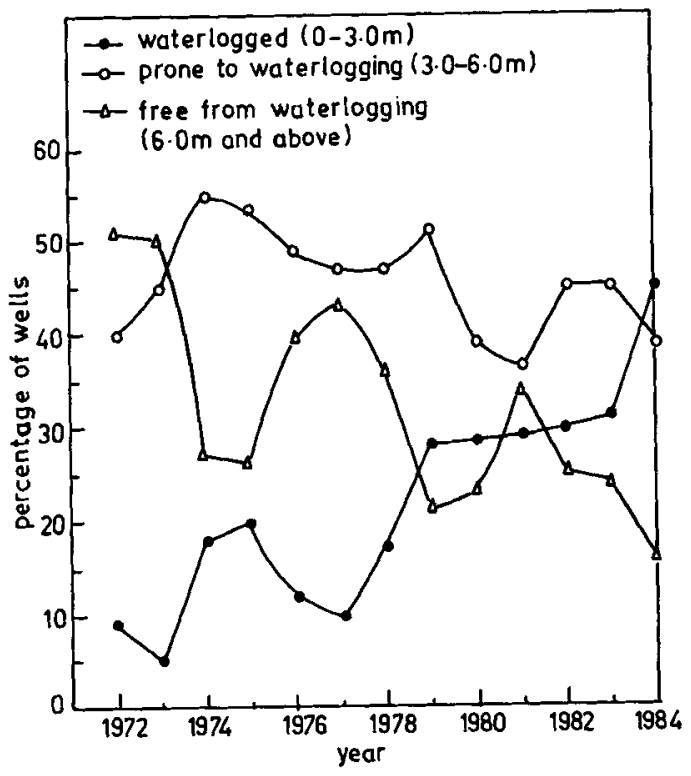

Figure 2. Changes in waterlogging in Sriramsagar command area. 
waterlogging have come down from 51 to $16 \%$. The water level contour maps of the command area, generated from the contour level maps, showing the areas waterlogged in $1977,1979,1982$ and 1984 are given in figures $3-6$. The contour level maps indicate the premonsoon levels of the water-table. The area waterlogged has been going up in the command area. As per the analysis 33 to $45 \%$ of the command area is waterlogged.

To examine statistically whether the trend of waterlogging has been increasing over the years, the graph of cumulative percent of observation wells and depth to water-table has been plotted (figure 7). The graph clearly indicates the stochastic dominance of waterlogged conditions in 1984 as compared to the previous years. Though in 1975 and 1978 the trend is reversed due to summer rains, the overall increasing trend is clearly evident.

\subsection{Reasons for waterlogging}

Waterlogging in the Sriramsagar Command Area has been increasing over the years due to the combined action of a number of factors, such as (i) nonlining of the canal and distributories, (ii) lack of drainage, (iii) poor withdrawal of ground water by pumping, and (iv) using heavy irrigation in areas identified only for light irrigation. The length of the canal is $146 \mathrm{kms}$ and till 1978 the canal was not lined. The lining work started in 1977 and by 1981 about $116 \mathrm{kms}$ were lined. No work on drainage has been undertaken, since there has been no financial provision for drainage in the project proposal. Ground water withdrawal by pumping has not picked up since it is costlier than surface water (rates of irrigation water are based on area under cropping). For irrigating one hectare of land using surface water, the cost is Rs. 75/- per hectare, whereas irrigating with ground water will cost Rs. 330/per ha, mainly in the form of electricity alone. The marginal cost of irrigation using canal water is zero for a farmer whereas it is higher in the case of farmers using ground water. Table 1 gives the comparative costs of irrigation using canal water

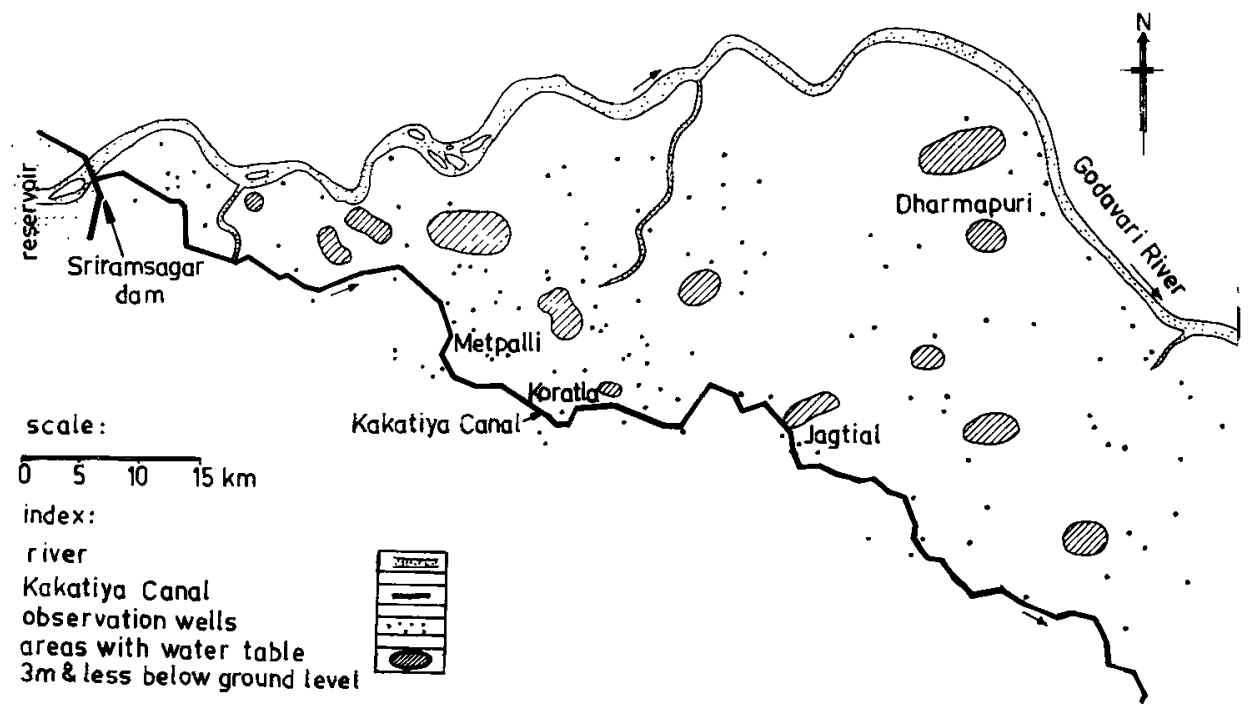

Figure 3. Waterlogging in Sriramsagar command area - 1977. 


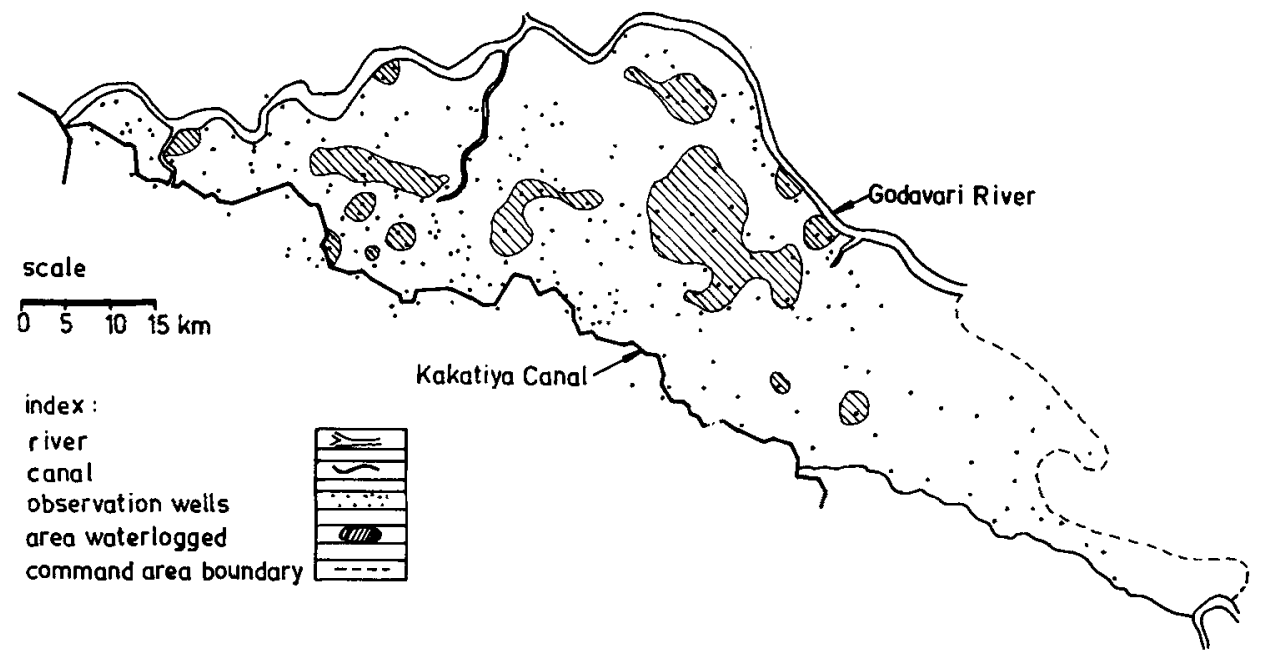

Figure 4. Waterlogging in Sriramsagar command area -1979.

and lift irrigation in Andhra Pradesh (Mitra \& Reddy 1985). Though there is a demonstration centre for promoting conjunctive use of water (surface + ground water) many of the farmers are not aware of the seriousness of the problem of waterlogging and possible corrective measures.

The problem is again an example of an environmental one caused by a fragmented approach to natural resource management. Land is a critical resource and for administrative convenience it is compartmentalized into Irrigation and Agriculture Departments. The technical, personal (of the farmer) and organiza-

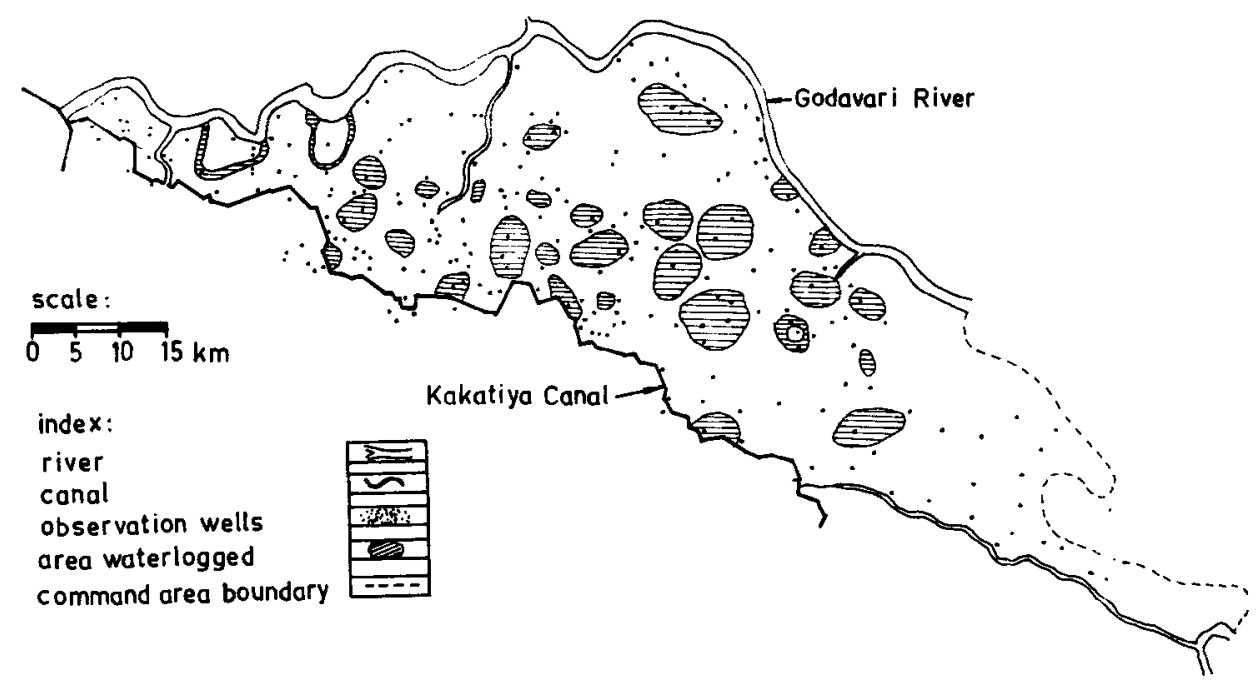

Figure 5. Waterlogging in Sriramsagar command area - 1982 . 


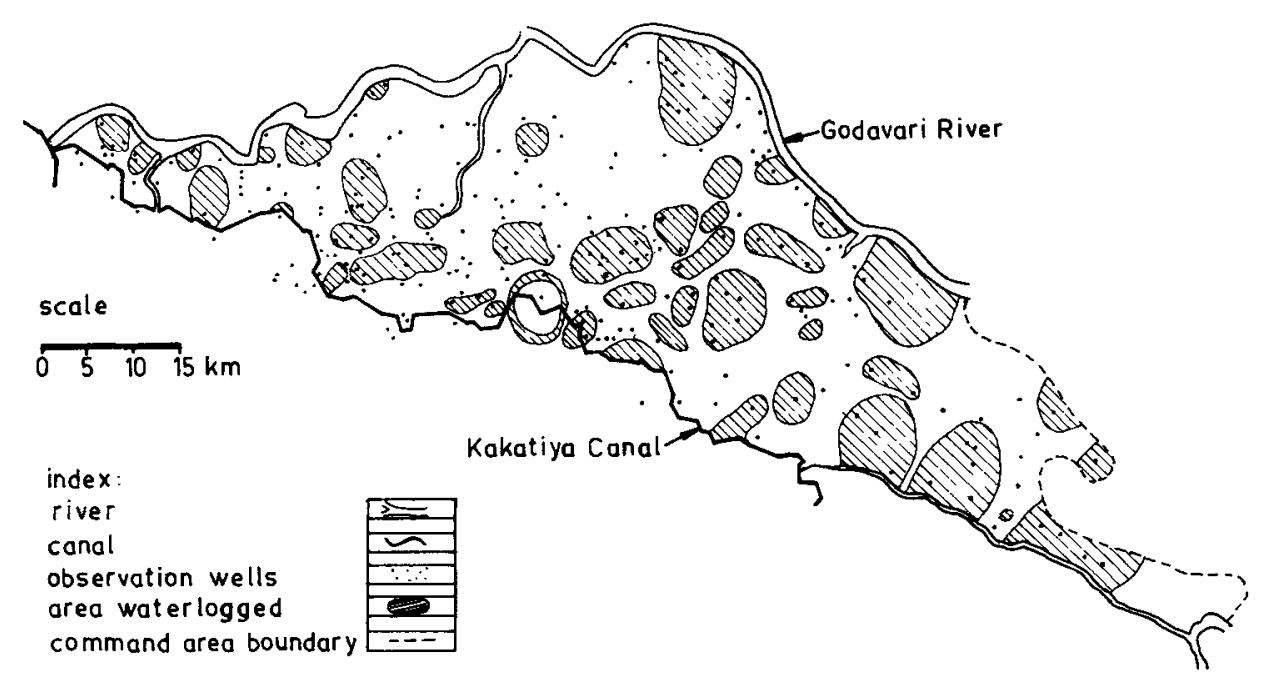

Figure 6. Waterlogging in Sriramsagar command area - 1984.

tional perspectives (Bowonder 1984) of various concerned agencies do not overlap (figure 8) and there is considerable divergence in perspectives. Unless the farmer and the officials from the Irrigation and the Agriculture departments consider the problem in a proper (common) perspective, waterlogging will continue to increase in irrigated areas.

One of the major problems in all command areas is the use of areas for cultivating crops needing heavy irrigation where they are meant only for light irrigation. The planned cropping pattern is $1: 2$ for heavy and light irrigation whereas the actual usage is $28700: 39300$ ha and this has created waterlogging in areas not having proper natural drainage. It is also difficult for the revenue officials to strictly implement the planned cropping patterns. To sum up, waterlogging is partly related to the socio-economic set-up in rural areas. Monitoring the irrigation, cropping and water use practices of a large number of farmers and making them adhere to the planned cropping pattern is practically a difficult problem and economically a costly proposition.

Table 1. Irrigation cost per hectare

\begin{tabular}{lccc}
\hline Item & $\begin{array}{c}\text { Diesel pumpset } \\
(3.6 \mathrm{~kW})\end{array}$ & $\begin{array}{c}\text { Electric pumpset } \\
(3.6 \mathrm{~kW})\end{array}$ & $\begin{array}{c}\text { Surface or } \\
\text { canal water }\end{array}$ \\
\hline $\begin{array}{l}\text { Capital cost (Rs) } \\
\begin{array}{l}\text { Annutized cost of } \\
\text { capital (Rs) }\end{array}\end{array}$ & $4,455.41$ & $3,227.24$ & Nil \\
$\begin{array}{l}\text { Operating expenses } \\
\text { (Rs/year) }\end{array}$ & $523.33^{*}$ & $379.07^{*}$ & $\mathrm{Nil}$ \\
& 419.80 & $331 \cdot 74$ & $\begin{array}{l}50 \cdot 0^{\#} \\
75 \cdot 0^{\# \#}\end{array}$ \\
\hline
\end{tabular}

* Life of pumpset $=20$ years; ${ }^{*}$ Irrigation cost for irrigated dry crop; ${ }^{*}$ "Irrigation cost wet crop. 


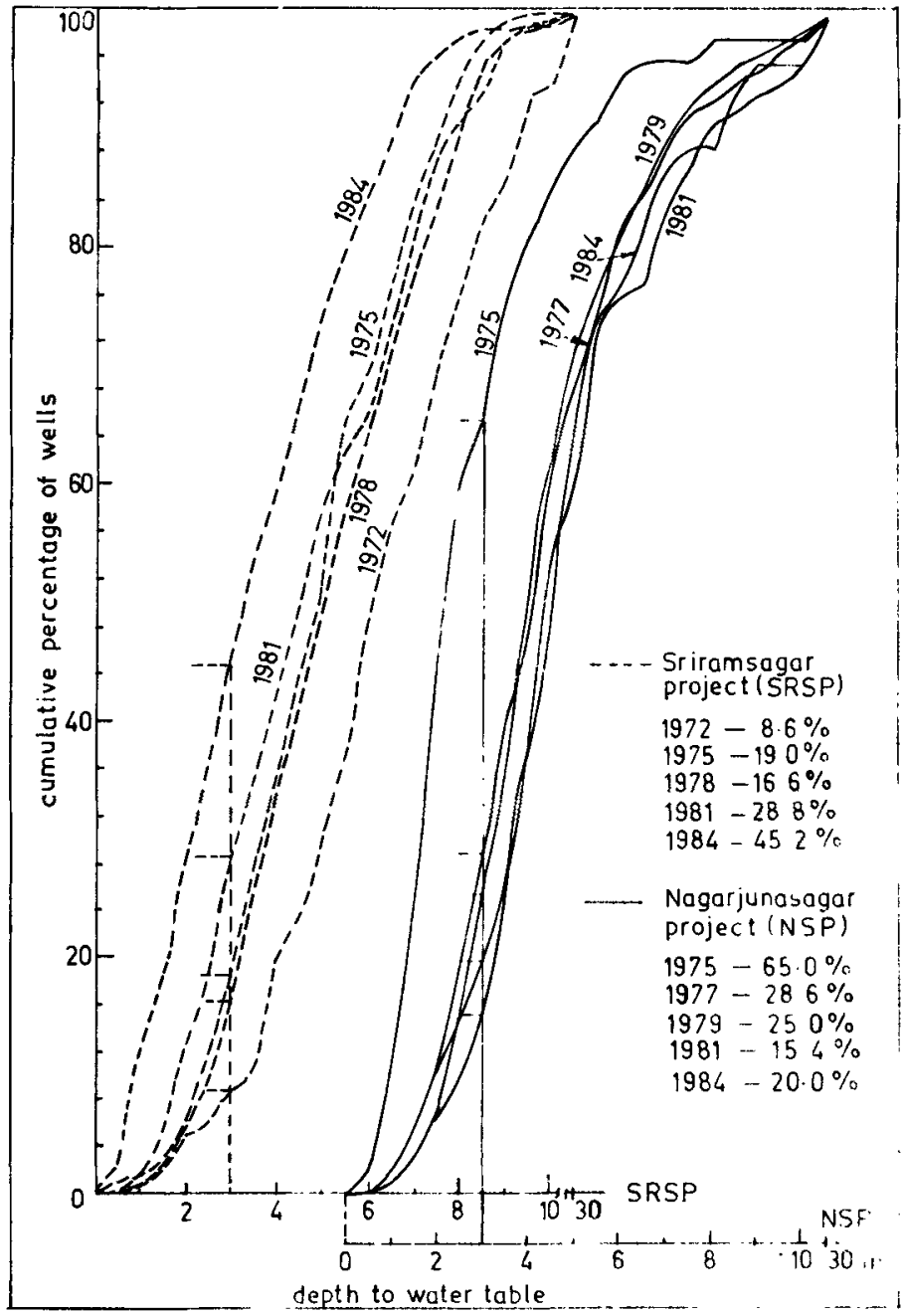

Figure 7. Trends in waterlogging in Sriramsagar and Nagarjunasagar projects.

\section{Nagarjunasagar Project}

The Nagarjunasagar Project (NSP) is a multipurpose reservoir constructed across the River Krishna in 1970, to irrigate 1.4 million hectares. The command area of the left canal consists of freely drained sandy loams. It was indicated in the project report that a majority of the area under the command of the Nagarjunasagar Project has adequate slopes, conducive to superficial run-off and drainage. The monitoring of the water-table fluctuations in the command area of the left bank was started in 1975 through a network of 125 observation wells covering an area of about $\mathbf{0 . 1 1 7}$ million hectares. The percentage of observation wells in a waterlogged condition was $65 \%$ in 1975 and it remained the same till 1978. The main canal was closed and lining of the canal started in 1979, when the wells in the waterlogged 

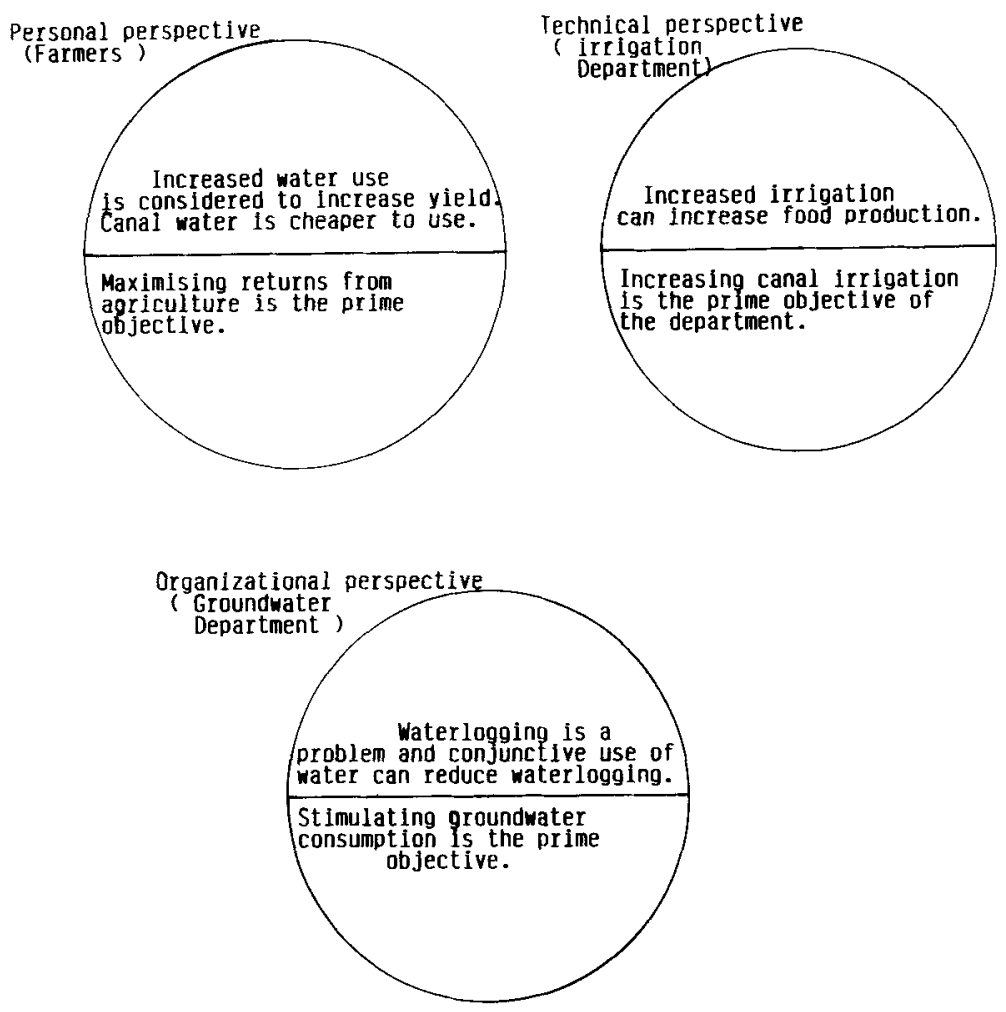

Figure 8. Multiple perspective analysis applied to waterlogging.

condition came down to $25 \%$, and then further dropped down to $20 \%$ by 1984 . Table 2 gives the percentage of wells manifesting waterlogging ( $0-3$ meters depth to water-table). It can be seen that from 1980 onwards wells free from waterlogging have increased to $23 \%$ by 1984 (as compared to $4 \%$ in 1978). The stochastic dominance chart (figure 7) indicates that the water-table has been progressively coming down in the case of the Nagarjunasagar command area. The reasons for the reduction of waterlogging have been the following:

(i) water is released in the canal for only 6 to 8 months in an year whereas in the SRS project it is released for 10 months in an year;

(ii) the canals are fully lined whereas in the SRS command area they are not lined completely;

Table 2. Percent distribution of water levels in observation wells in the Nagarjunasagar Project

\begin{tabular}{lrrrrrrrrrrrr}
\hline \multirow{2}{*}{$\begin{array}{c}\text { Depth to water-table } \\
(\mathrm{m})\end{array}$} & 1975 & 1976 & 1977 & 1978 & 1979 & 1980 & 1981 & 1982 & 1983 & 1984 \\
\cline { 2 - 11 } & 65 & 68 & 30 & 60 & 25 & 40 & 15 & 10 & 14 & 20 \\
\hline $0-3$ (Waterlogged) & 29 & 28 & 54 & 36 & 56 & 51 & 61 & 57 & 61 & 57 \\
$3-6$ (Prone to waterlogging) & 28 & 4 & 16 & 4 & 19 & 9 & 24 & 33 & 25 & 23 \\
6 (Free from waterlogging) & 6 & 4 &
\end{tabular}


(iii) the soil in the SRSP command area is red loam and in this kind of soil seepages are greater. The run-off index is lower for red soils because of high porosity. The infiltration rate in these soils is of the order of 4 to $6 \mathrm{cms} / \mathrm{hr}$.

The locations where waterlogging existed in 1976, are indicated in figure 9, and by 1978 the area increased (figure 10). In 1979, the Nagarjunasagar left canal was closed for lining work and consequent to this the waterlogging decreased considerably (figure 11) by 1981 . Only one irrigation release is provided in the NSP left canal. There was further reduction in waterlogging, as can be seen from figure 12 , by 1984 . Inspite of the fact that the proportion of heavy irrigation is high in NSP, the incidence of waterlogging is lower because of the shorter duration of release of irrigation water.

\section{Conclusions}

The two examples clearly indicate that the extent of waterlogging in irrigation projects is a complex problem requiring much more attention. At the project initiation stage, detailed analyses have to be carried out for estimating the possible occurrence of waterlogging. This may need development of computer simulation models linking soil permeability characteristics, run-off characteristics, irrigation schedules, cropping patterns, ground water levels, hydrological structure of the watershed, ground water withdrawal characteristics, drainage patterns, land development patterns etc. At the time of the preparation of a feasibility report itself such models have to be constructed and simulated. This should form part of

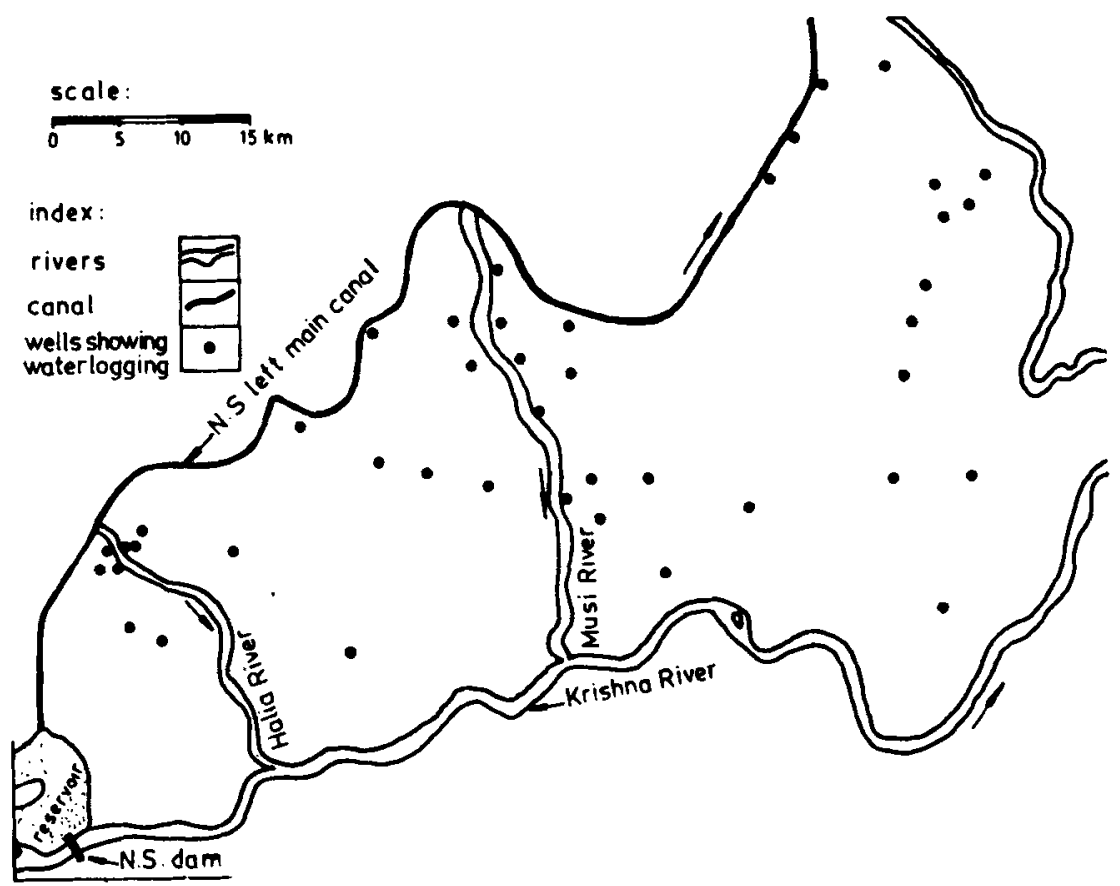

Figure 9. Waterlogging in Nagarjunasagar left canal command area - 1976. 


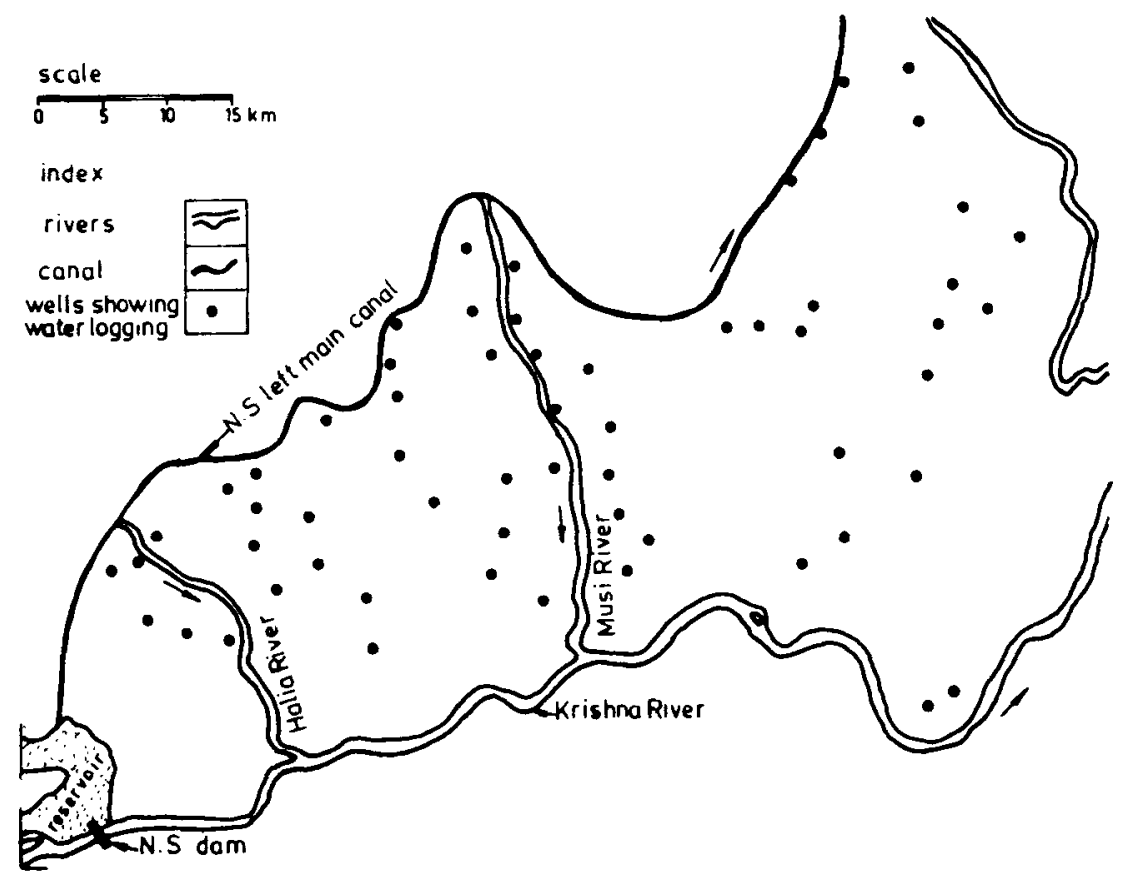

Figure 10. Waterlogging in Nagarjunasagar keft canal command area-1978.

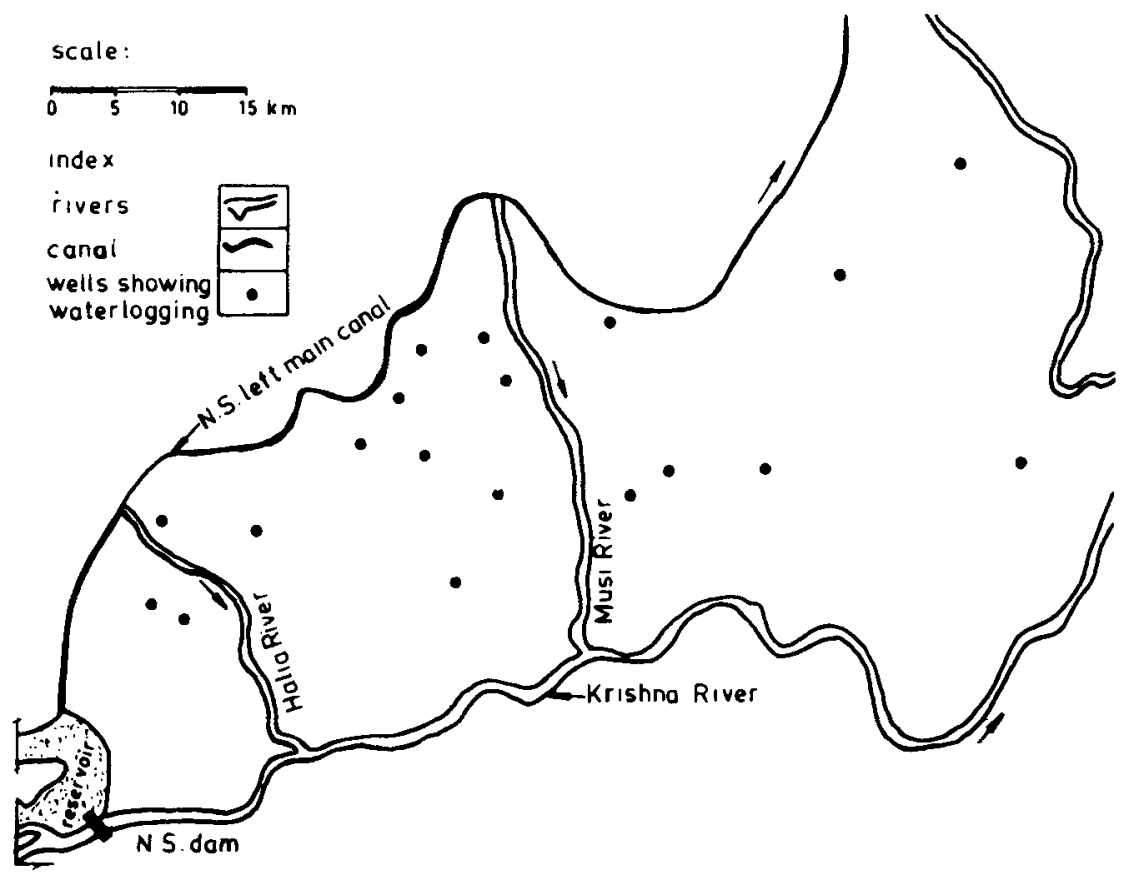

Figure 11. Waterlogging in Nagarjunasagar left canal command area -1981. 


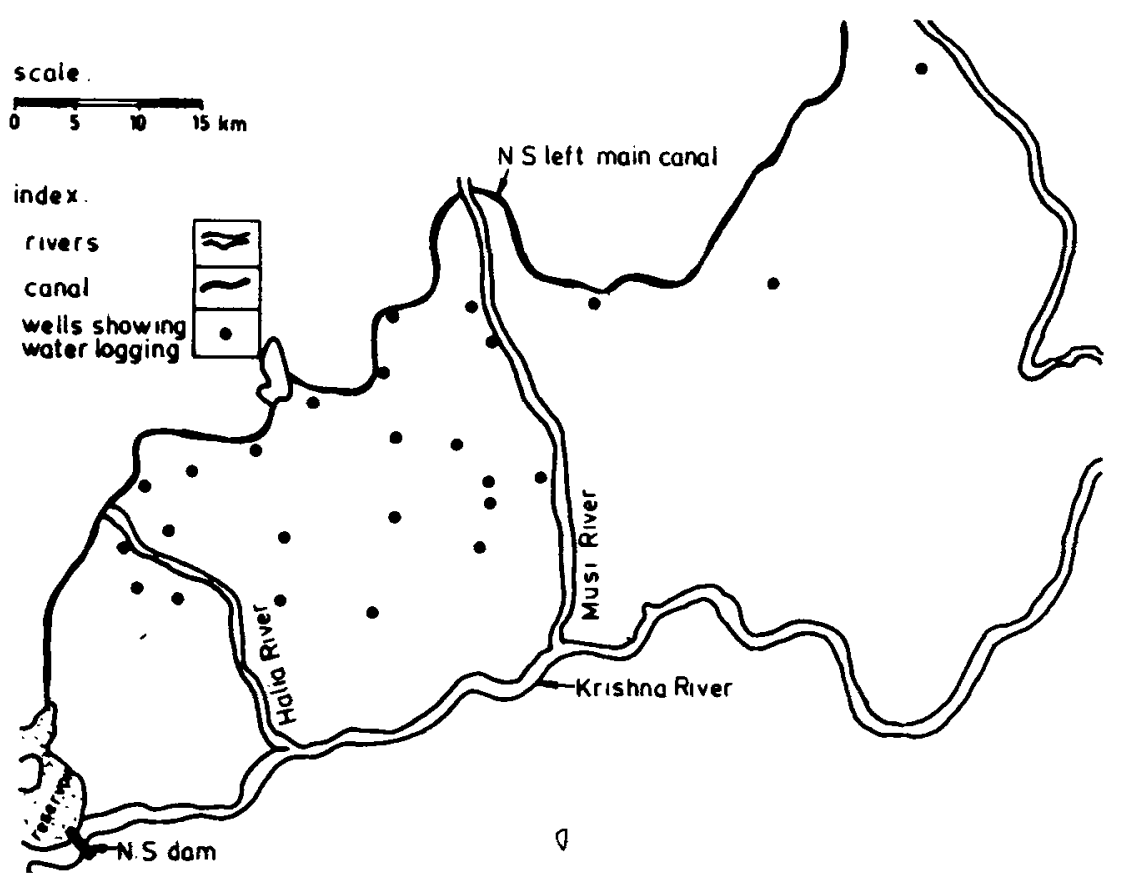

Figure 12. Waterlogging in Nagarjunasagar left canal command area - 1984.

the environmental impact assessment exercise. One of the prerequisites for doing this may be developing a cadre of multidisciplinary technologists with modelling and simulation expertise.

Inspite of the fact that the two command areas discussed are close to each other and irrigation practices are similar, the magnitude of the problem of waterlogging is severe in Sriramsagar. Coming to the remedial measures in the case of the Sriramsagar Project, the major interventions needed are discussed below.

(i) Providing drainage: A detailed assessment of drainage (vertical and horizontal drains) should be taken up and implemented immediately. This may need large investments, and provisions for this have to be made.

(ii) Lining the canal: The canal and major distributories should be lined immediately to reduce seepages. The irrigation is being extended further downstream and at the time of extension itself, canal lining work should be carried out.

(iii) Conjunctive use of water: Water withdrawal is low because irrigation water is released for 10 months in an year. For reducing waterlogging, about 1035 million $\mathrm{cu} \mathrm{m}$ of water may have to be drawn out from the ground every year. This will be equivalent to 4500 pumps of $3.6 \mathrm{~kW}$ capacity working at a rate of $8 \mathrm{hr}$ a day for 150 days every year.

(iv) Creating public awareness: The main reason for increased waterlogging is poor public awareness regarding conjunctive use of water and the risks of waterlogging. Educating farmers regarding the impact of waterlogging on agricultural productivity and efficient use of water for irrigation is the most critical corrective action. The marginal cost of the conjunctive use of water will be less than the marginal benefits 
that a farmer will obtain through increased yields. Demonstration experiments have already proved that the marginal costs of increasing the water-withdrawal using pumps will be about Rs. 1049 per annum per hectare whereas the increased yield per hectare will be Rs. 1500 per annum (Ground Water Department 1983). (v) Reducing the duration of water release: The option of reducing the duration of water release vis-à-vis the possibility of extending the irrigation to downstream areas should be properly evaluated. The water saved by reducing the irrigation in upper areas can be used for extending the command area under irrigation. Moreover, stoppage of irrigation water during the rabi season (SeptemberDecember) should be considered in waterlogged areas, specially in the light of higher ground water levels during the monsoon season.

(vi) Cropping pattern: The farmers tend to change the cropping pattern frequently and this makes it very difficult for the project authorities to adhere to the irrigation plan. Rice requires water only for 4 months whereas sugarcane needs water for almost 10 months in an year. Through public participation, planning of cropping patterns may be institutionalized.

(vii) Charges for irrigation: The charges for irrigation consist of only a nominal charge for water use and there are no lumpsum charges to be paid against the capital costs of irrigation projects. The irrigation water charges should be fixed considering the opportunity costs of water. Prior to providing irrigation, reasonable lumpsum charges may have to be levied to compensate for the per capita cost of the irrigation projects in order to make them financially viable and developmentsustainable.

Unless similar steps are planned in other major irrigation projects, the effectiveness of irrigation will not be fully realized. Water is a critical resource in India and unless water use management and planning gets institutionalized the existing inefficient practices will continue.

The authors would like to thank the Department of Environment, Government of India, for providing financial support for undertaking this study.

\section{References}

Agarwal A 1985 Econ. Pol. Weekly 20: 1035-1037

Barney G O 1980 The Global Report 2000 to the President, The Technical Report, vol. 2, US Government, Washington

Bokhari S M H 1980 Watersupply Manage. 10: 305-332

Bowonder B 1984 Environ. Professional 6: 216-224

Bowonder B, Ravi C 1983 Int. J. Water Resour. Dev. 1: 157-171

Bowonder B, Ravi C 1984 Waterlogging from irrigation projects-an environmental management problem, Administrative Staff College of India, Hyderabad

Brown L R 1983 Third World Q. 5: 103-119

Dettmann K 1983 Appl. Geogr. Dev. 18: 119-126

Eckholm E P 1976 Losing ground (New York: Norton)

Elgabaly M M 1980a Water management for arid lands in developing countries. Water development. supply and management (ed.) A K Biswas (New York: Pergamon) vol. 13

Elgabaly M M 1980b Water management for arid lands in developing countries. Water development, supply and management (ed.) A K Biswas (New York: Pergamon) vol. 13 
Et Hinnawi E, Hashmi M H 1982 Global environmental issues. Vol. 7. Natural Resources and Environment Series (Dublin: Tycooly)

Federal Bureau of Statistics 1984 Pakistan Statistical Yearbook, Report FBS-143, Reproduction and Printing Unit, Statistical Division, Karachi

Ground Water Development 1983 Conjunctive use of ground water with canal waters-field demonstration in Sriramsagar Project command area, Government of Andhra Pradesh, Hyderabad (unpublished mimeograph)

Holdgate M W, White G F 1977 Environmental issues. Scope report 10 (London: John Wiley)

Mitra G K, Reddy M S 1985 Prajnan 14: 63-76

National Commission on Agriculture 1976 Resource Development, Report 5, Ministry of Agriculture, Government of India, New Delhi

Polunin N 1979 Environ. Conserv. 6: 105-109

Ruddle K, Manshard W 1981 Renewable natural resources and the environment. Vol. 2. Natural Resources and Environment Series (Dublin: Tycooly)

Smil V 1982 Bull. Atomic Sci. 38: 18-23

United Nations 1982 The state of the environment, 1972-82, United Nations Environment Programme, Nairobi

Vohra B B 1980 A policy for land water, Sardar Patel Memorial Lecture, Department of Environment, Government of India, New Delhi

Widstrand C 1980 Water conflicts and research priorities (London: Pergamon)

Worthington E B 1977 Arid-land and irrigation in developing countries-environmental problems and effects (Oxford: Pergamon) 